\title{
JM
}

Volume 7 No. 1 (April 2019)

(C) The Author(s)

\section{HUBUNGAN PENGETAHUAN SUMBER INFORMASI DUKUNGAN KELUARGA TERHADAP KEJADIAN PRURITUS VULVAE SAAT MENSTRUASI DI SMPN 10 BENGKULU SELATAN}

\author{
RELATIONSHIP OF KNOWLEDGE SOURCES OF INFORMATION FAMILY \\ SUPPORT ON THE EVENT OF VULVAE PRURITES WHEN \\ MENSTRUCTIONIN SMPN 10SOUTH BENGKULU
}

\author{
TAUFIANIE ROSSITA \\ PROGRAM STUDI KEBIDANAN (DIII) \\ FAKULTAS ILMU KESEHATAN UNIVERSITAS DEHASEN BENGKULU \\ Email: taufianirossita255@gmail.com
}

\begin{abstract}
ABSTRAK
Organ genitalia merupakan komponen penting bagi pria dan wanita. Namun didominasikan pada wanita karena wanita memiliki sistem reproduksi yang sensitif terhadap suatu penyakit bahkan keadaan penyakit lebih dihubungkan dengan fungsi dan kemampuan terhadap kesehatan reproduksinya. Tujuan penelitian Untuk mengetahui hubungan pengetahuan, sumber informasi dan dukungan keluarga terhadap kejadian pruritus vulvae saat menstruasi. Metode penelitian ini menggunakan deskriptif analitik dengan pendekatan cross sectional, sampel penelitian ini mahasiswi kelas II SMPN 10 Bengkulu Selatan tahun 2015 dengan menggunakan Total Sampling terhadap 67 orang, analisis data dengan menggunakan univariat dan bivariat menggunakan uji Chi squaere. Hasil penelitian berdasarkan uji univariat dan bivariat diperoleh gambaran responden yang memiliki kejadian pruritus vulvae saat menstruasi sebanyak 40 siswi (59,7\%). Yang memiliki pengetahuan kurang sebanyak 43 siswi (64,2\%). Yang memiliki sumber informasi kurang sebanyak 31 siswi ( 46,3\% ). Yang memiliki dukungam keluarga kurang sebanyak 39 orang $(58,2 \%)$. Hasil uji statistik bivariat kejadian pruritus vulvae saat menstruasi di peroleh nilai $\mathrm{p}=0,012$. Maka dapat disimpulkan ada hubungan antara pengetahuan, sumber informasi, dukungan keluarga dengan kejadian pruritus vulvae saat menstruasi. Dari penelitian ini penulis memberikan saran untuk para guru agar menambahkan dan memperbaharui informasi kesehatan terutama mengenai pentingnya perilaku hidup bersih dan sehat serta melakukan pembinaan secara rutin kepada para siswi.
\end{abstract}

Kata Kunci : Dukungan Keluarga, Kejadian Pruritus Vulvae, Pengetahuan, Sumber Informasi

\begin{abstract}
Organ external are essential components for men and women.But didominasikan in woman because women have reproductive systems sensitive to a disease even the state of disease more connected with its function and the ability on health reproduction. The purpose of research to know relations knowledge, a source of information and family encouragement to events pruritus vulvae when menstrual.Research methodology it uses descriptive analytic with the
\end{abstract}


approach cross sectional, research sample areas a student of class ii smpn 10 bengkulu south 2015 by using total of sampling to 67 people, data analysis by using univariat and bivariat use test chi squaere. The results of the study based on the univariat and bivariat obtained picture of respondents who have scene pruritus vulvae when menstrual as many as 40 of ( 59,7 \% ). Who has knowledge less some 43 of ( 64,2\%). Have the information less thirty-one of ( 46,3\%) .Having dukungam poor families as many as 39 people $(58,2 \%)$. The results of statistical tests bivariat scene pruritus vulvae when period in get value $p=0,012$. So can be concluded there was a correlation between knowledge, a source of information, family encouragement to events pruritus vulvae when menstrual .From the study writer give advice to teachers in order added and update health information especially about the importance of the clean and healthy living and provide guidance routinely to the face.

\section{Keywords: Support families, the Incidence of Pruritus Vulvae, Knowledge, Indormation Sources}

\section{PENDAHULUAN}

Organ genitalia merupakan komponen penting bagi pria dan wanita. Namun didominasikan pada wanita karena wanita memiliki sistem reproduksi yang sensitif terhadap suatu penyakit bahkan keadaan penyakit lebih dihubungkan dengan fungsi dan kemampuan terhadap kesehatan reproduksinya. Organ genitalia sangat jarang dibahas dikarenakan terkesen tabu, namun seperti kita ketahui vagina perempuan memiliki fungsi reproduksi "melangsungkan keturunan", dengan mengenal dan mempelajari maka kita akan lebih tahu bagaimana merawat organ genitalia dan menjaganya dengan benar.(Jufri, 2011)

Seseorang yang tidak memiliki pemahaman tentang kesehatan reproduksi akan cenderung mengabaikan kesehatan reproduksi dan pada akhirnya ia akan memiliki tindakan yang membahayakan bagi dirinya sendiri. Salah satu akibat kurangnya pemahaman personal hygiene genitalia adalah terjadinya gangguan kesehatan reproduksi seperti keputihan, infeksi saluran kemih (ISK), penyakit radang panggul (PRP) dan kemungkinan terjadi kanker leher rahim, sehingga dibutuhkan informasi yang baik mengenai kesehatan reproduksi agar remaja memiliki pemahaman yang baik dan dapat mencegah ancaman penyakit reproduksi.(Ali, 2009)
Berdasarkan data World Health Organization ( 2012), kelompok usia remaja (10-19 tahun) pada tahun 2010 menempati seperlima jumlah penduduk dunia dan $83 \%$ di antaranya hidup di negara-negara berkembang.(Andira, 2010)

Berbagai penelitian mengenai remaja menunjukkan bahwa remaja sering kali salah dalam membersihkan genitalia, seperti salah dalam membasuh organ genitalia dari arah belakang ke depan, membersihkan organ genitalia menggunakan sabun biasa atau cairan pembersih yang tidak jelas komposisi kandungannya, atau menabur bedak, bahkan menyemprotkan parfum di dalam vagina.Di Indonesia pada tahun $2008,80 \%$ di antaranya pernah mengalami Pruritus vulvae. Dimana sebanyak 20\% mengalami Pruritus vulvae secara akut dan 40\% mengalami Pruritus vulvae secara kronis. Sedangkan yang yang mengalami Pruritus vulvae secara kronis, 20\% diantaranya disebabkan karena adanya jamur, bakteri dan virus yang muncul karena personal higiene dan higiene menstruasi yang kurang (Arikunto, 2010). Pengetahuan tentang kesehatan reproduksi sangat diperlukan oleh masyarakat, terutama pada remaja. Karena semakin baik pengetahuan remaja mengenai kesehatan reproduksi maka akan mempengaruhi perilaku remaja dalam menjaga kesehatan genetalianya. Pengetahuan yang minim menunjukkan bahwa remaja perlu diberikan 
informasi yang baik dan positif melalui tenaga kesehatan, orang tua, teman sebaya dan guru.(Azwar, 2012)

$\begin{array}{llr}\text { Kesehatan } & \text { reproduksi } & \text { (kespro) } \\ \text { merupakan masalah vital dalam }\end{array}$
pembangunan kesehatan, karena tidak akan dapat diselesaikan dengan jalan kuratif saja, namun yang lebih penting adalah dengan melakukan upaya preventif. Kesehatan reproduksi menjadi perhatian pemerintah, karena masalah ini menjadi masalah yang serius sepanjang hidup. Pemerintah tetap melihat penanganan persoalan kesehatan reproduksi remaja dalam konteks perundangundangan yang berlaku dan kondisi sosial budaya masyarakat Indonesia. Menstruasi merupakan keluarnya darah dari kemalauan setiap bulan akibat meluruhnya dinding rahim endometrium yang mengandung pembuluh darah karena sel telur (ovum) tidak di buahi (Djadjakusumah, 2010)

Menstruasi atau haid adalah perubahan fisiologis dalam tubuh wanita yang terjadi secara berkala dan dipengaruhi oleh hormon reproduksi baik FSH-Estrogen atau LHProgesteron. Periode ini penting dalam hal reproduksi. Pada manusia, hal ini biasanya terjadi setiap bulan antara usia remaja sampai menopause. Pada wanita siklus menstruasi rata-rata terjadi sekitar 28 hari, walaupun hal ini berlaku umum, tetapi tidak semua wanita memiliki siklus menstruasi yang sama, kadang-kadang siklus terjadi setiap 21 hari hingga 30 hari. Biasanya, menstruasi rata-rata terjadi selama 5 hari, kadang-kadang menstruasi juga dapat terjadi sekitar 2 - 7 hari paling lama 15 hari. Jika darah keluar lebih dari 15 hari maka itu termasuk darah penyakit (Indah, 2012) Untuk menampung darah haid, wanita yang mengalami menstruasi harus memakai pembalut, baik pembalut tradisional misalnya kain ataupun pembalut modern yang sudah ada dengan berbagai keunggulan. Ada pembalut yang terbuat dari herbal, sehingga nyaman dipakai, ada juga pembalut yang di desain dengan ukuran panjang 29 hingga 35 $\mathrm{cm}$ untuk dipakai saat tidur atau bagi mereka yang darah haidnya keluar dengan deras. Pembalut harus diganti minimal dua kali sehari untuk mencegah agar tidak terjadi infeksi pada vagina atau gangguan-gangguan lainnya (Indriastuti, 2009)

Gangguan pada wanita saat menstruasi sangatlah luas, salah satunya terjadi iritasi atau rasa gatal di sekitar vulva dan lubang vagina. Daerah ini amat peka bila disentuh, sering kali rasa gatal ini memicu para remaja putri untuk menggaruknya, sehingga dapat menyebabkan rasa perih dan kondisi yang lebih tidak nyaman, bekas garukan sering terlihat bila pemeriksaan dilakukan oleh dokter. Jika kulit vagina tergores oleh kuku yang tajam atau benda lain, walaupun pada permukaannya kelihatan tidak rusak, namun hal ini dapat menyebabkan infeksi.(Istiari, 2012)

Hygiene menstruasi merupakan kebersihan diri pada saat menstruasi. Hygiene menstruasi sangatlah penting, karena bila penanganan selama haid tidak steril maka dapat mengakibatkan infeksi alat reproduksi. Sedangkan infeksi alat reproduksi ini mempunyai dampak yang buruk ke masa depan atau dengan kata lain mempunyai dampak seumur hidup, seperti kemandulan. (Kusmiran, 2011)

Kebersihan diri saat menstruasi berawal dari menjaga kebersihan diri, terutama menjaga kebersihan organ reproduksi. Udara panas cenderung lembab dan berkeringat membuat tubuh menjadi lembab, terutama pada daerah reproduksi yang menyebabkan bakteri berkembang biak sehingga menimbulkan bau yang tidak sedap dan mudah menimbulkan penyakit (Notadmodjo, 2010)

Iritasi ini merupakan tanda awal vaginitis, Pruritus vulvae biasanya terjadi pada malam hari, ketika sedang tidur kemungkinan menggaruk daerah tersebut tanpa menyadarinya dan dapat menyebabkan beberapa memar dan berdarah. Pada tahap selanjutnya pruritus vulvae mempengaruhi kehidupan sosial seorang wanita, karena dapat menganggu aktivitas dalam kehidupan sehari-hari (Perdede, 2012)

Pruitus vulvae kronis tersebut disebabkan oleh jamur, bakteri, dan virus 
yang muncul karena buruknya personal hygiene dan hygiene menstruasi, karena alergi dari pembalut kewanitaan, serta karena kelainan patologik pada vulva. Ketidak adekuatan hygiene merupakan salah satu faktor risiko terjadinya kanker vulva (Pudiastuti, 2012)

Hasil penelitian Indah (2012), menunjukkan bahwa remaja putri di SMPN 1 Ngimbang Lamongan $100 \%$ pernah mengalami pruritus vulvae saat menstruasi, yaitu 12 siswi kelas I, 67 siswi kelas II dan 21 siswi sisanya adalah kelas III yang mengalami pruritus vulvae. Dan hasil penelitian juga menunjukan pada umumnya remaja masih kurang memahami tentang vulva hygiene saat mentruasi. Informasi tentang kesehatan reproduksi penting untuk disebarluaskan terutama mengenai infeksi saluran reproduksi, karena perempuan lebih mudah terkena infeksi saluran reproduksi dibandingkan dengan pria (Sarwono, 2010) Hasil survei awal di Sekolah SMPN 10 Bengkulu Selatan, dari 10 siswi didapatkan 10 siswi tersebut pernah mengalami pruritus vulvae saat menstruasi dan 8 diantara mereka mengatakan belum mengetahui penyebab terjadinya pruritus vulvae. Sedangakan 2 siswi lainya mengatakan mengetahui penyebab terjadinya pruritus vulvae dari keluarga (Notoadmojo, 2011)

Berdasarkan latar belakang yang ada maka penulis ingin mengetahui hubungan pengetahuan, sumber informasi dan dukungan keluarga terhadap kejadian pruritus vulvae saat mentruasi pada siswi kelas II di SMPN 10 Bengkulu Selatan

\section{METODE PENELITIAN}

Penelitian ini termasuk dalam penelitian kuantitatif dengan penelitian deskriptif analitik dengan menggunakan desain cross sectional yaitu suatu penelitian pada beberapa populasi yang diamati dalam waktu yang bersamaan pengukuran terhadap variabel independen (Pengetahuan, sumber informasi, dukungan keluarga) dan variabel dependen (Kejadian pruritus vulvae saat menstruasi) dimana pengukuran terhadap variabel dependent dan independent dapat dilakukan dalam waktu bersamaan sehingga cukup efektif dan efisien (Notoatmodjo, 2010)

Penelitian ini dilakukan di SMPN 10 Bengkulu Selatan Penelitian ini dilakukan pada bulan Juni tahun 2015. Populasi adalah keseluruhan objek atau subjek yang berada pada suatu wilayah dan memenuhi syaratsyarat tertentu berkaitan dengan masalah penelitian,atau keseluruhan unit, individu dalam ruang lingkup yang akan diteliti. Populasi dalam penelitian ini adalah siswi kelas II SMPN 10 Bengkulu Selatan Tahun 2015 yang berjumlah 67siswi.sample dari populasi yang telah diketahui jumlahnya yaitu sebanyak 67 siswi. Besarnya sample dalam penelitian ini dihitung menggunakan rumus Solvin maka didapatkan hasil yang ada berjumlah 67 siswi.Teknik pengambilan sampel pada penelitian ini adalah Total Sampling menjelaskan teknik Total Sampling.

\section{HASIL PENELITIAN}

Pada analisis univariat data yang telah dipeoleh dari hasil pengumpulan data disajikan dalam bentuk tabel distribusi frekuensi dan teks. Dimana variabel independennya yaitu media pembelajaran dan minat belajar, variabel dependen yaitu motivasi belajar.

Data Univariat dalam penelitian ini terdiri dari pengetahuan, sumber informasi, dan dukungan kluarga. Pada penelitian ini, terdapat penelitian yang akan di kelompokan meliputi variabel dependen kejadian pruritus vulvae saat menstruasi.

Pada penelitian ini menggunakan analisia univariat dan bivariat. Analisa univariat adalah analisis untuk mengetahui gambaran dari tiap variabel independen (pengetahuan, sumber informasi, dukungan keluarga) dan variabel dependen (kejadian pruritus vulvae saat menstruasi) data yang telah dipeoleh dari hasil pengumpulan data disajikan dalam bentuk tabel distribusi frekuensi dan teks. Dimana variabel independen dan dependen

Dimana variabel independennya yaitu 
pengetahuan, sumber informasi, dukungan keluarga variabel dependen yaitu kejadian prurtus vulvae saat menstruasi.

Analisa ini juga di gunakan menyederhanakan atau meringkas kumpulan data hasil pengukuran sehingga kumpulan data tersebut menjadi informasi yang berguna.

Data Univariat dalam penelitian ini terdiri dari pengetahuan, sumber informasi, dukungan keluarga dependen yaitu kejadian pruritus vulvae saat menstruasi.

Analisis bivariat dilakukan untuk mengetahui hubungan antara 2 variabel yaitu variabel bebas (pengetahuan, sumber informasi, dukungan keluarga) dengan variabel terikat (kejadian pruritus vulvae saat menstruasi) dengan menggunakan uji chi square pada $\alpha=$ $5 \%$. Bila nilai $p>\alpha(5 \%)$ maka keputusannya Ha ditolak dan sebaliknya nilai $p<\alpha(5 \%)$ maka keputusanya Ho ditolak yaitu ada hubungan pengetahuan sumber informasi dukungan keluarga terhadap kejadian pruritus vulvae saat menstruasi pada siswi kelas II di SMPN 10 Bengkulu Selatan Tahun 2019

Pada angka kejadian pruritus vulvae saat menstruasi berdasarkan distribusi frekuensi menunjukan bahwa rendah pengetahuan memiliki nilai lebih besar sehingga distribusi frekuensi pengetahuan, sumber informasi, dukungan keluarga dan distibusi frekuensi menunjukan bahwa kejadian pruritus vulvae saat menstruasi pada siswi memiliki pengaruh yang besar.

Dan distibusi frekuensi menunjukan bahwa pengetahuan yang kurang siswi kelas II perlu dilakukan pembaruan pengetahuan para siswi mengenai hidup bersih dan sehat, agar para siswi dapat menjaga kebersihan diri.

Penyajian data dalam penelitian ini meliputi pengetahuan sumber informasi dan dukungan keluarga terhadap kejadian pruritus vulvae saat menstruasi pada siswi kelas II di SMPN 10 Bengkulu Selatan tahun 2019. Pada penelitian ini, terdapat penelitian yang akan di kelompokan menjadi 3. penyajian data dalam penelitian ini meliputi pengetahuan, sumber informasi dan dukungan keluarga.

Penyajian data dalam penelitian ini meliputi pengetahuan, sumber informasi, dukungan keluarga, terhadap kejadian pruritus vulvae saat menstruasi. Pada penelitian ini, terdapat penelitian yang akan di kelompokan meliputi variabel dependen kejadian pruritus vulvae saat menstruasi. Berdasarkan hasil olah data menggunakan komputerisasi didapatkan gambaran pengetahuan, sumber informasi dan dukungan keluarga pada tabel berikut:

Tabel. Distribusi Frekuensi Pengetahuan, Sumber Informasi dan DukunganKeluarga Terhadap Kejadian Pruritus Vulva Saat Menstruasi Tahun 2019

\begin{tabular}{ccc}
\hline Variabel & Frekuensi (f) & $\begin{array}{c}\text { Presentase } \\
(\%)\end{array}$ \\
\hline $\begin{array}{c}\text { Pengetahun } \\
\text { Kurang }\end{array}$ & 43 & 64,2 \\
\hline Baik & 24 & 35,8 \\
\hline $\begin{array}{c}\text { Sumber Informasi } \\
\text { Kurang }\end{array}$ & 36 & 53,7 \\
\hline Baik & 31 & 46,3 \\
\hline $\begin{array}{c}\text { Dukungan Keluarga } \\
\text { Kurang }\end{array}$ & 39 & 58,2 \\
\hline Baik & 28 & 41,8 \\
\hline
\end{tabular}

Sumber : Hasil Olahan Data Komputerisasi 2019

Penyajian data dalam penelitian ini meliputi pengetahuan ,sumber informasi dan dukungan keluarga terhadap kejadian pruritus vulvae saat menstruasi. Pada penelitian ini, terdapat penelitian yang akan di kelompokan meliputi variabel dependen kejadian pruritus vulvae saat menstruasi. Dibawah ini merupakan penjelasan yang mengenai pengumpulan data dari hasil analisis univariat yang memiliki variabel independen dan dependen. Dimana variabel independen di tabel yaitu pengetahuan, sumber informasi dan dukungan keluarga sedangkan variabel dependen. Kejadian pruritus vulvae saat menstruasi.

Dari tabel di atas dengan distribusi frekuensi data disajikan dalam bentuk tabel dan teks. Dari tabel 1 menunjukkan siswa yang memiliki pengetahuan kurang sebanyak 31 orang $(72,1 \%)$ sedangkan mahasiswa yamg memiliki pengetahuan baik sebanyak 9 
orang $(37,5 \%)$.

Distribusi frekuensi pengetahuan di SMPN 10 Bengkulu Selatan tahun 2019. Diperoleh siswi yang memiliki pengetahuan kurang dengan rincian 31 siswi (72,1\%) pernah mengalami kejadian pruritus vulvae saat menstruasi dan 12 siswi $(27,9 \%)$

Distribusi frekuensi sumber informasi di SMPN 10 Bengkulu Selatan tahun 2019. Diperoleh siswi, yang memiliki sumber informasi kurang dengan rincian 23 siswi $(74,2 \%)$ pernah mengalami kejadian pruritus vulvae saat menstruasi dan 8 siswi $(25,8 \%)$

Distribusi frekuensi dukungan keluarga di SMPN 10 Bengkulu Selatan tahun 2019. Diperoleh dukungan keluarga yang kurang berperan sebanyak 39 dari 67 responden, dengan rincian 29 siswi $(74,6 \%)$ pernah mengalami kejadian pruritus vulvae saat menstruasi dan 10 siswi $(25,6 \%)$.

hasil analisis hubungan pengetahuan sumber informasi dan dukungan dengan kejadian pruritus vulvae saat menstruasi diperoleh bahwa dari 43 siswi yang memiliki pengetahuan kurang sebanyak 31 orang $(72,1$ $\%$ ) yang memiliki pengetahuan baik sebanyak 9 orang ( $37,5 \%$ ). Dari 31 yang memiliki sumber informasi kurang sebanyak 23 orang ( $74,2 \%$ ) yang memiliki sumber informasi baik sebanyak 17 orang ( 47,2\%) Sedangkan. Dari 39 siswi yang dukungan keluarga kurang sebanyak 229 orang ( 74,6 \%) yang memiliki dukungan keluarga baik 11 orang ( $39,3 \%$ ) Dari hasil uji statistik didapat nilai $\mathrm{P}=0,008$ berarti $\mathrm{P}<0,05$, sehingga dapat disimpulkan sehingga terdapat hubungan yang signifikan antara dukungan keluarga dengan kejadian pruritus vulvae saat menstruasi dari nilai OR 4,482 , artinya bahwa siswi yang mendapatkan peran keluarga berpeluang 4,482 (4) kali berperilaku baik dalam pencegahan pruritus vulvae saat menstruasi dibandingkan siswi yang kurang mendapatkan peran keluarga.

\section{PEMBAHASAN}

Rancangan penelitian ini menggunakan pendekatan cross sectional yaitu semua variabel dikumpulkan dalam waktu yang bersamaan sehingga menimbulkan kelemahan yaitu tidak terpenuhinya urutan waktu dimana penyebab harus mendahului akibat. Mengingat keterbatasan waktu, dana, dan kemampuan peneliti maka dalam penelitian ini hanya mengetahui distribusi frekuensi hubungan antara hubungan pengetahuan sumber informasi dan dukungan keluarga terhadap kejadian pruritus vulvae saat menstruasi pada siswi kelas II di SMPN 10Bengkulu Selatan tahun 2019.

Penelitian ini menggunakan data primer yang di peroleh dari penyebaran kuesioner pada siswi Kelas II SMPN 10 Bengkulu Selatan Tahun 2019. Penelitian ini tidak terlepas dari keterbatasan, di antaranya pengetahuan yang dimiliki oleh penulis, waktu penelitian yang di lakukan peneliti sangat singkat.

Alatukur yang di gunakan adalah kuesioner yang bersifat subjektif karena kebenaran data dari hasil kuesioner sangat bergantung pada kejujuran responden dalam menjawab dan waktu yang terbatas di dalam penyebaran kuesioner dikarenakan jadwal siswi kelas II SMPN 10 Bengkulu Selatan.

\section{PENGETAHUAN}

Pengetahuan dapat di ukur dengan menggunakan alat ukur kuesioner yaitu menjawab pertanyaan sebanyak 15 pertanyaan. Hasil keseluruhan kuesioner di akumulasikan dan di bagikan dengan jumlah responden sehingga di dapatkan nilai pengetahuan kurang sebanyak 31 orang $(72,1$ \%) sebanyak 9 orang $(37,5 \%$ ) siswi yang memiliki pengetahuan baik.

Hasil penelitian senada dengan penelitian Styowati ada Hubungan Anatara Pengetahuan Dan Perilaku Tentang Vulva Hygiene Dengan Kejadian Pruritus Vulvae Saat Menstruasi Pada Pelajar Putri Pengetahuan merupakan hasil dari tahu, dan ini terjadi setelah orang melakukan penginderaan terhadap objek tertentu. Penginderaan terjadi melalui pancainderea manusia yakni indera penglihatan, pendengaran, penciuman, rasa 
dan raba. Sebagian besar pengetahuan manusia diperoleh mata dan telinga. Pengetahuan merupakan domain yang sangat penting untuk terbentuknya tindakan seseorang.

Pengetahuan sebagian besar diperoleh melalui mata dan telinga, karena dari pengalaman dan penelitian terbukti bahwa perilaku yang didasari oleh pengetahuan akan lebih langgeng dari pada perilaku yang tidak didasari pengetahuan. Pengetahuan atau kognitif merupakan domain yang sangat penting dalam membentuk tindakan seseorang. untuk melakukan tugas atau pekerjaan dengan baik.

Proses yang didasari oleh pengetahuan kesadaran dan sikap yang positif, maka perilaku tersebut akan bersikap langgeng. Sebalik nya apabila perilaku tersebut tidak didasari oleh pengetahuan dan kesadaran maka tidak akan berlangsung lama.

Pengetahuan (Knowledge) juga diartikan ssebagai hasil penginderaan manusia atau hasil tahu seseorang terhadap objek melalui indera yang dimilikinya (mata, hidung dan sebagainya), dengan sendirinya pada waktu penginderaan sehingga menghasilkan pengetahuan. Hal tersebut sangat dipengaruhi oleh intensitas perhatian dan presepsi terhadap objek.

Pengetahuan seseorang biasanya diperoleh dari pengalaman yang berasal dari berbagai macam sumber seperti, media poster, kerabat dekat, media massa, media elektronik, buku petunjuk, petugas kesehatan, dan sebagainya. Pengetahuan dapat membentuk keyakinan tertentu, sehingga seseorang berperilaku sesuai dengan keyakinannya tersebut(Istiarti., 2011)

Dalam Notoatmodjo (2011), pengetahuan atau kognitif merupakan domain yang sangat penting untuk terbentuknya tindakan seseorang (overt behavior). Dari pengalaman dan penelitian terbukti bahwa perilaku yang didasari oleh pengetahuan akan lebih langgeng dari pada perilaku yang tidak didasari oleh pengetahuan.

Apabila penerimaan perilaku baru atau diadopsi perilaku melalui proses seperti ini, dimana didasari oleh pengetahuan, kesadaran dan sikap yang positif, maka perilaku tersebut akan bersifat langgeng. Berdasarkan penelitian yang dilakukan Bart (1994) dapat dikatakan bahwa perilaku yang dilakukan atas dasar pengetahuan akan lebih bertahan dari pada perilaku yang tidak didasari oleh pengetahuan. Jadi pengetahuan sangat dibutuhkan agar masyarakat dapat mengetahui mengapa mereka harus melakukan suatu tindakan sehingga perilaku masyarakat dapat lebih mudah untuk diubah kearah yang lebih baik

Pengetahuan seseorang biasanya diperoleh dari pengalaman yang berasal dari berbagai macam sumber, misalnya : media massa, media elektronik, buku petunjuk, petugas kesehatan, media poster, kerabat dekat dan sebagainya.

\section{Gambaran Pengetahuan kejadian Pruritus Vulvae Saat Menstruasi Pada Siswi Kelas II Di SMPN 10 Bengkulu Selatan Tahun 2019}

Berdasarkan distribusi frekuensi diatas, menunjukkan bahwa dari 67 responden, didapatkan 43 siswi $(64,2 \%)$ memiliki pengetahuan yang kurang, artinya perlu dilakukan pembaruan pengetahuan para siswi mengenai hidup bersih dan sehat, agar para siswi dapat menjaga kebersihan diri.

Berdasarkan hasil penelitian Setyowati tahun 2014 Hubungan Anatara Pengetahuan Dan Perilaku Tentang Vulva Hygiene Dengan Kejadian Pruritus Vulvae Saat Menstruasi Pada Pelajar Putri SMPN 1 Kartasura didapatkan 10 siswi tersebut pernah mengalami pruritus vulvae saat menstruasi dan 8 diantara mereka mengatakan belum mengetahui penyebab terjadinya pruritus vulvae. 2 siswi lainya mengatakan mengetahui penyebab terjadinya pruritus vulvae dari keluarga. Pengetahuan merupakan hasil dari tahu, dan ini terjadi setelah orang melakukan penginderaan terhadap objek tertentu.

Penginderaan terjadi melalui
pancainderea manusia yakni indera


penglihatan, pendengaran, penciuman, rasa dan raba. Sebagian besar pengetahuan manusia diperoleh mata dan telinga

Pengetahuan merupakan hasil dari tahu, dan ini terjadi setelah orang melakukan penginderaan terhadap objek tertentu. Penginderaan terjadi melalui pancainderea manusia yakni indera penglihatan, pendengaran, penciuman, rasa dan raba. Sebagian besar pengetahuan manusia diperoleh mata dan telinga. Pengetahuan merupakan domain yang sangat penting untuk terbentuknya tindakan seseorang.

Pengetahuan sebagian besar diperoleh melalui mata dan telinga, karena dari pengalaman dan penelitian terbukti bahwa perilaku yang didasari oleh pengetahuan akan lebih langgeng dari pada perilaku yang tidak didasari pengetahuan. Pengetahuan atau kognitif merupakan domain yang sangat penting dalam membentuk tindakan seseorang.

\section{Gambaran Sumber Informasi Kejadian Pruritus Vulvae Saat Menstruasi Pada Siswi Kelas II Di SMPN 10 Bengkulu Selatan Tahun 2019}

Berdasarkan distribusi frekuensi di atas, menunjukkan bahwa dari 67 responden, didapatkan hasil $31 \quad(46,3 \%)$ siswi mendapatkan sumber informasi yang kurang baik.

Penelitian Siti Nurjanah didapatkan hasil, ada hubungan antara sumber informasi dengan pengetahuan hygiene menstruasi dengan nilai $p$ value $<0,05$.

Informasi merupakan fungsi penting untuk membantu mengurangi rasa cemas seseorang. Semakin banyak informasi dapat mempengaruhi atau menambah pengetahuan seseorang dan dengan pengetahuan menimbulkan kesadaran yang akhirnya seseorang akan berperilaku sesuai dengan pengetahuan yang dimilikinya.

Sumber informasi adalah segala hal yang dapat digunakan oleh seseorang sehingga mengetahui tentang hal yang baru dan mempunyai ciri-ciri yaitu : (1) dapat dilihat, dibaca dan dipelajari. (2) diteliti, dikaji dan dianalisis. (3) dimanfatkan dan dikembangkan didalam kegiatan-kegiatan pendidikan, penelitian, laboratorium. ditranformasikan kepada orang lain.

Beberapa fungsi sumber informasi yaitu : a) fungsi informasi, fungsi memberikan informasi ini diartikan bahwa media massa adalah penyebar informasi bagi pembaca, pendengar atau pemirsa. b) fungsi pendidikan, media massa merupakan sarana pendidikan bagi khalayaknya, karena media massa banyak menyajikan hal-hal yang sifatnya mendidik. Salah satu cara mendidik yang dilakukan media massa adalah melalui pengajaran nilai, etika, serta aturan-aturan yang berlaku kepada pemirsa atau pembaca. c) fungsi memengaruhi, fungsi memengaruhi dari media massa secara implisit terdapat pada tajuk atau editorial, feature, iklan, artikel dan sebagainya.

\section{Gambaran Dukungan Keluarga Terhadap Kejadian Pruritus Vulvae Saat Menstruasi Pada Siswi Kelas II Di SMPN 10 Bengkulu Selatan Tahun 2019}

Berdasarkan distribusi frekuensi di atas, menunjukkan bahwa dari 67 responden, didapatkan kurangnya dukungan keluarga sebanyak 39 (58,2\%). Berdasarkan penelitian Amatalah diketahui dari hasil analisis tabulasi silang menunjukkan bahwa proporsi praktik membersihkan organ genitalia eksterna yang kurang baik pada tingkat peran orang tua yang kurang baik $(20,0 \%)$ dibandingkan dengan yang cukup $(7,1 \%)$ dan yang baik $(12,1 \%)$. Hasil uji spearman rank nilai p lebih besar dari 0,05 yaitu $0,405>0,05$, dapat diartikan tidak ada hubungan antara peran orang tua dengan praktik membersihkan organ genitalia eksterna.

Keluarga berfungsi sebagai sebuah kolektor dan diseminator (penyebar) informasi tentang dunia. Menjelaskan tentang pemberian saran, sugesti, informasi yang dapat digunakan mengungkapkan suatu masalah. Manfaat dari dukungan ini adalah dapat menekan munculnya suatu stressor 
karena informasi yang diberikan dapat menyumbangkan aksi sugesti yang khusus pada individu. Aspek-aspek dalam dukungan ini adalah nasehat, usulan, saran, petunjuk dan pemberian informasi. Keluarga bertindak sebagai sebuah bimbingan umpan balik, membimbing dan menengahi pemecahan masalah, sebagai sumber dan validator indentitas anggota keluarga diantaranya memberikan support, penghargaan, perhatian.

\section{KESIMPULAN}

Berdasarkan analisa dan pembahasan pada bab VI dan VII maka kesimpulan yang dapat diambil sesuai tujuan penelitian adalah sebagai berikut, dapat diambil kesimpulan. Distrubusi frekuensi angka terjadi kejadian pruritus vulvae saat menstruas yang pernah mengalami sebanyak 40 siswi (59,7\%), jumlah pengetahuan siswi yang kurang juga memiliki nilai sebanyak 43 santri $(64,2 \%)$ dan para siswi yang memiliki sumber informasi kurang baik sebanyak 31 (46,3\%) didapatkan juga dukungan keluarga yang kurang baik sebanyak 39 (58,2\%).Dari hasil uji statistik didapat nilai $r$ value $=0,012$ berarti $r<0,05$, sehingga dapat disimpulkan ada hubungan yang signifikan antara pengetahuan dengan kejadian pruritus vulvae saat menstruasi di SMPN 10 Bengkulu Selatan Tahun 2019.Dari hasil uji statistik didapat nilai $r$ value $=0,008$ berarti $r<r$ $(0,05)$, sehingga terdapat hubungan yang signifikan antara dukungan keluarga dengan kejadian pruritus vulvae saat menstruasi di SMPN 10 Bengkulu Selatan Tahun 2019.

Saran

Agar menambahkan dan memperbaharui informasi kesehatan terutama mengenai pentingnya perilaku hidup bersih dan sehat serta melakukan pembinaan secara rutin kepada para siswi. a. Para siswi harus selalu menjaga kebersihan diri, baik pada saat menstruasi maupun tidak. Selalu mengganti pembalut sesering mungkin pada saat menstruasi dan tidak sembarangan menggunakan sabun pembersih vagina. Diharapkan pembuatan skripsi ini dapat bermanfaat sebagai tambahan bacaan untuk memahami pentingnya kebersihan diri sehingga dapat memberikan pengetahuan baru di perpustakaan dan dapat di jadikan wawasan bagi para pembaca atau mahasiswa.

\section{DAFTAR PUSTAKA}

Al-Jufri.H sumber InformasiManajemen Pendidikan Jakarta: PT.SmartGrafika; 2011.

AliM. PsikologiRemaja. Jakarta :BumiAksara; 2009.

Andira

D.SelukBelukKesehatanReproduksiWani ta. Yogyakarta: AT- Books; 2010.

Arikunto.ProsedurPenelitianSuatupendekatan praktik. Jakarta: PT. Rineka Cipta; 2010.

AzwarS.SikapManusiaEdisi II. Yogyakarta: PustakaPelajar; 2002.

Budiarto. MetodologiPenelitiankwantitatif, EGC, Jakarta; 20012.

Djadjakusumah. Penatalaksanaan Pruritus Anogital. Surabaya: PT. Surya Ilmu; 2010.

Indah Tn. Kejadian Pruritus Vulvae SaatMenstruasipadaremajaputri.

Surabaya:

FakultasKesehatanMasyarakat:

UniversitasAirlangga; 2012.

Indriastuti. Perilaku Hygiene

RemajaPutriSaatMenstruasi. Jurnal.

Surakarta: UniversitasMuhammadiyah; 2009.

Istiari.Teori Pengetahuan dan Sikap. Jakarta: Rhineka Cipta; 2011

KusmiranE. Kesehatan Reproduksi Remaja dan Wanita. Jakarta: Salemba Medika; 2011.

NotoadmodjoS. Ilmu perilaku Kesehatan. Perdede N. Masa Remaja. Jakarta: Solaryo Media; 2012.

Notoadmojo. Kesehatan Masyarakat Ilmu \& Seni. Jakarta :Rineka Cipta; 2012. Soekidjo N Metodologi Penelitian Kesehatan. Jakarta :Rineka Cipta; 2011.

Notoatmodjo. Metodologi Penelitian Kesehatan. Jakarta : PT Rineka Cipta; 2010. 
Nanang M. Metode Penelitian Kuantitatif Analisiisi \& Analisis data Sekunder. Jakarta: Raja grafindo Persada. Hal 74 : 2010.

Notoadmodjo.Promosi kesehatan dan perilaku kesehatan. Jakarta :Rineka Cipta; 2010.

Pudiastuti.3 FasePentingpadaWanita. Jakarta: KompasGramedia; 2012.

Ridwan M.Metode dan Tehnik Penyusunan Tesis Bandung: Alpabet; 2012.

Sarwono. PsikologiRemaja. Jakarta: PT. Raja GravidoPersada; 2006. 